\title{
Civilisations
}

Revue internationale d'anthropologie et de sciences

humaines

58-1 | 2009

American Afrocentrism(e)s américains

\section{Barack Obama and the Ironies of Afrocentrism}

\section{Algernon Austin}

URL : http://journals.openedition.org/civilisations/1946

DOI : 10.4000/civilisations. 1946

ISSN : 2032-0442

\section{Éditeur}

Institut de sociologie de l'Université Libre de Bruxelles

\section{Édition imprimée}

Date de publication : 31 août 2009

Pagination : 113-128

ISBN : 2-87263-026-0

ISSN : 0009-8140

\section{Référence électronique}

Algernon Austin, «Barack Obama and the Ironies of Afrocentrism », Civilisations [En ligne], 58-1 | 2009, mis en ligne le 31 août 2012, consulté le 19 avril 2019. URL : http://journals.openedition.org/ civilisations/1946; DOI : 10.4000/civilisations.1946 


\title{
Barack Obama and the Ironies of Afrocentrism
}

\author{
Algernon AUSTIN
}

Résumé : On pourrait penser que Barack Obama, un homme noir américain ayant un père africain, serait positivement disposé à l'égard de l'Afrocentrisme, un mouvement social qui cherche à connecter les Américains noirs à l'Afrique sur le plan culturel. Mais au contraire, Obama est le défenseur d'une politique post-raciale et universaliste qui représente un défi fondamental pour la pensée raciale de l'Afrocentrisme. D'un autre côté, Obama a passé plusieurs années dans l'Eglise afrocentriste Trinity United Church of Christ, et partage aussi certaines idées soutenues par des Afrocentristes éminents. Cet article utilise des écrits et des discours d'Obama pour retracer ses interactions avec, et ses rejets de l'Afrocentrisme. Ce faisant, il présente les croyances et les idéaux respectifs d'Obama et de l'Afrocentrisme.

Mots-clés : Afrocentrisme, Barack Obama, Molefi Asante, Etats-Unis, Trinity United Church of Christ.

\begin{abstract}
One might assume that Barack Obama, a black American man with an African father, would be positively disposed to Afrocentrism, a social movement that seeks to connect black Americans culturally to Africa. But instead, Obama is committed to a post-racial and universalist politics that represents a fundamental challenge to the racial thinking of Afrocentrism. On the other hand, Obama spent many years in the Afrocentric Trinity United Church of Christ and has ideas that are in agreement with ideas held by prominent Afrocentrists. This article uses Obama's writings and speeches to trace his interactions with and rejections of Afrocentrism. In doing so, it presents an understanding of the beliefs and ideals of both Obama and Afrocentrism.
\end{abstract}

Key words: Afrocentrism, Barack Obama, Molefi Asante, United States of America, Trinity United Church of Christ. 
A mong black Americans, President Barack Obama has some of the closest and deepest ties to Africa. He has visited Africa when most black Americans have not. His father was Kenyan, and his father's side of his extended family still mainly resides in Africa. One irony of Obama's life is that his African ties lead him away from Afrocentrism, not toward it.

A second irony is that Obama, although not Afrocentric, was still a member of an Afrocentric church led by the black nationalist Reverend Jeremiah A. Wright, Jr. This irony is likely a testimony to power of black nationalism in Chicago, particularly during the "Afrocentric era" of the late-1980s and 1990s. Although Harlem is the globallyidentified city of American blackness (Jackson 2001: 17-23) and Los Angeles or Oakland might arguably have been the fount of the Black Power Movement ${ }^{1}$, no city embodied the Afrocentric era quite like Chicago. It is surprising that Obama, a mainstream politician, found himself tied to such a controversial church, but less surprising when one considers that he was active as a politician in black Chicago during the Afrocentric era. Without much effort he could have ended up connected to the even more controversial Chicago-based, black nationalist Minister Louis Farrakhan of the Nation of Islam as Jesse Jackson did in the 1980s (Rueters 1988).

Obama originally planned to write a book discussing Afrocentrism (Obama 2004b: xiii) but changed his mind and ended up with the autobiography Dreams of My Father: A Story of Race and Inheritance. Nonetheless, Dreams of My Father reveals some of his experiences with Afrocentrism and many reasons why Afrocentrism would be problematic for him. Actually, we can gain insight into Afrocentrism and into Obama by examining Afrocentrism through Obama's eyes and Obama through Afrocentric eyes. There have been Afrocentric ideas and organizations throughout black American history, but this article discusses the relatively popular and intense Afrocentric activism during the late1980s and 1990s in the United States, which truly constituted an "Afrocentric era". Most of the major organizations of the Civil Rights Movement of the 1950s and 1960s still exist today, but no one would argue that that movement continues today. Similarly, there is Afrocentism in the United States today, but it is not of the intensity of the Afrocentric era.

In addition to the Afrocentric era, scholars of black nationalism have noted the classical era of black nationalism from the mid-nineteenth century to the early twentieth century (Moses 1978) and the Black Power era of the late 1960s and early 1970s (see Van Deburg 1992). Classical black nationalists hoped to establish a black state for black Americans outside of the geographic United States, but their vision of this black nation was culturally European. Marcus Garvey who desired to "assist in civilizing the backward tribes of Africa" (quoted in Hill and Rudisell 1983: lii) is the most famous of the classical black nationalists. Most Black Power nationalists were more interested in having blacks establish and take control of specific institutions within the United States than in separating politically from the United States. The Black Panthers who were involved in policing the police and running programs to benefit black urban communities (Van Deburg 1992) is the most famous of the Black Power nationalists. Afrocentric era black nationalism

1 The Black Panther Party is the most common signifier of the Black Power Movement, and that organization began in 1967 in Oakland, California. But a strong argument can be made that US Organization did at least as much to shape the Movement. US Organization was established in 1965 in Los Angeles, California. See Austin (2006a), Chapter 4. 
was an intellectual and cultural movement with no significant political goals. Within the academy, Molefi Kete Asante's writings on Afrocentrism were extremely important to spreading the viewpoint. When one compares the different black-nationalist eras, one notices a decline in political nationalism and an increase in cultural nationalism over time (Austin 2006a: 189-193)².

\section{Following and Not Following Jesse Jackson}

In 1988, Jesse Jackson, a black civil rights leader ${ }^{3}$, was one of the most prominent men in America - of any race. That year, Jackson completed his second attempt to become the President of the United States. Although he was unsuccessful, he won a number of primaries and progressed much further along the road to the White House than any black person had before him. Barack Obama, therefore, followed in Jackson's footsteps on his path to the American presidency.

In December of 1988, Jackson redefined black America - literally. Jackson held a press conference and told the media that blacks preferred to be called "African Americans" (New York Times 1988). He argued, "To be called African-Americans has cultural integrity. It puts us in our proper historical context" (New York Times 1988). Afrocentrism, in its most academic sense ${ }^{4}$, is precisely about this idea - centering black American cultural identities in Africa and African history. As a man coming off of tremendous success in a presidential campaign, even though he did not win, Jackson had the power to do this without controversy. As a result, Jackson played an important part in re-forging the link between black American identity and Africa.

Although Barack Obama has stronger connections to Africa than Jackson, it is hard to imagine Obama attempting to connect black identities to Africa in any way. Jesse Jackson's civil rights career was based on speaking for blacks. During Jackson's Presidential campaigns, he spoke for working class Americans facing deindustrialization (Kilborn 1988). Politicians routinely speak for specific constituencies, obscuring the differences between themselves and the groups they claim to represent. Obama does not do this. In Dreams of My Father, he states:

I can't even hold my experience as being somehow representative of the black American experience...; indeed, learning to accept that particular truth - that I can embrace my black brothers and sisters, whether in this country or in Africa, and affirm a common destiny without pretending to speak to, or for, all our various struggles - is part of what this book's about (Obama 2004b: xvi).

Obama is comfortable not speaking for any particular group, because he does not see himself as belonging to any one single group. He is most comfortable speaking for all groups, speaking for the universal. When speaking to Americans, he speaks for all Americans. As he stated in the 2004 Democratic Convention, "there is not a liberal

2 For more detailed discussion of the Afrocentric era and other black nationalist eras, see Austin (2006a).

3 Jesse Jackson's prominence began as a leader within the Southern Christian Leadership Conference (SCLC) when it was headed by Martin Luther King Jr. Jackson headed the Chicago branch of SCLC's Operation Breadbasket.

4 There was a popular Afrocentrism and an academic Afrocentrism during the Afrocentric era. See Austin (2006a), Chapters 5 and 6. 
America and a conservative America - there is the United States of America. There is not a Black America and a White America and Latino America and Asian America - there's the United States of America" (Obama 2004a).

Although Obama identifies as a black American (Obama 2004b: xvi), he is not a typical black American. His desire to speak for the universal is likely influenced by his multiracial and international background. His mother was white. His step-father was Asian. He has a half-Asian, half-sister, and he lived in Indonesia for a period of his childhood (Obama 2004b: 28-52, 440). Even the places where Obama lived were extremely multiracial. Hawaii has a very multiracial racial landscape compared with the rest of the United States (Schaefer 2000: 347-351). Indonesia, too, is, from an Asian perspective, very multiracial ${ }^{5}$ and very multicultural for Asia (Obama 2004b: 28-52). Although Obama identifies as a black American, his life experience is far more multiracial and multicultural than that of most Americans of any race. From this perspective, it is not surprising that this particular black American would want to speak for all races and not just blacks.

\section{Centered in Africa, but which Africa?}

A black person speaking for Americans of all races is not at all Afrocentric. Afrocentrism is about connecting black Americans culturally to Africa and rejecting the idea that black Americans are culturally similar to white Americans. Molefi Kete Asante, one of the leading Afrocentric scholars, argues "Africans in the Americas are ... Africans" and "African American culture and history represent developments in African culture and history" (Asante 1987: 10). In 1989, Asa Hilliard, another leading Afrocentric scholar, lamented the fact that in school curricula "there is no presentation of the cultural unity among Africans and the descendents of Africans in the African Diaspora" (Hilliard 1990: xx-xxi). From an Afrocentric perspective, a black person cannot truly speak for all Americans because black people are culturally African. Additionally, African culture and European culture - the culture of whites - are presumed to be fundamentally different and antagonistic. America, therefore, for Afrocentrists, is a political vessel holding peoples with fundamentally different cultures and fundamentally different values. Barack Obama assumes that he is drawing Americans of different races and political perspectives to recognize their shared common American values. But from an Afrocentric perspective, there are no common American values of any significance.

The popular assertion that blacks are culturally African and the celebration of this idea represented a major break from the past. Many black Americans, like other Americans, often viewed Africa as a place of backwardness and inferiority (Austin 2006b: 6, 9-10). Black Americans did not first come to the realization that they had African ancestry in the late 1980s, but it was in the 1980s that many black Americans were able to re-imagine an Africa that was not perceived as backward and inferior.

In fact, the Afrocentric vision of Africa presented Africans as the creators of the greatest civilization of all human history. The rapper Wise Intelligent of the music group X-Clan argued, "Black people are the mothers and fathers of the highest forms of civilization ever built on this planet... Plato, Socrates, and so forth, they learned from black masters of Egypt" (quoted in Decker 1993: 76). John Henrik Clarke stated plainly, "Egypt gave birth

5 The racial formation of Indonesia is very similar to Malaysia. See Austin (2006a), Chapter 1 and Chapter 8 for a discussion of the social construction of race and the racial categories of Malaysia. 
to what later would [become] known as 'Western Civilization'" (Clarke 1997: xvii). Asa Hilliard gushed, "There is no code of values and virtues anywhere on the planet, ancient or modern, that exceeds the MAATian system articulated in the Nile Valley thousands of years ago" (Hilliard 1998: 7).

This re-conceptualization of Africa was accomplished, in part, by avoiding contemporary Africa and especially the messy political and economic realities of contemporary Africa. Afrocentrism, at least the more academic version, relied on connecting blacks with ancient Egypt. As Asante argued in the 1980s, "the centerpiece of Afrocentric theory was a reconnection, in our minds, of Egypt to Africa" (Asante 1988: ix). Ancient Egypt allowed for Afrocentrists to focus on and also to imagine an Africa of great civilizations, kings, queens and scientists.

President Barack Obama's engagement with Africa, however, was with contemporary Africa and with messy details that makes imagining a cultural unity between Africans and Americans difficult. In Dreams of My Father, Obama revealed that he was aware of the ethnic conflicts in Africa. His father suffered because he challenged Kenya's ethnic politics. His half-sister Auma tells him the story:

President [Jomo] Kenyatta [the first Prime Minister of post-colonial Kenya] was from the largest tribe, the Kikuyus. The Luos, the second largest tribe, began to complain that Kikuyus were getting all the best jobs.... The vice-president, Odinga, was a Luo, and he said the government was becoming corrupt. . . . Oding a tried to start his own party, but was placed under house arrest as a Communist. Another popular Luo minister, Tom M'boya, was killed by a Kikuyu gunman. Luos began to protest in the streets, and the government police cracked down. People were killed. All this created more suspicion between the tribes (Obama 2004b: 214).

Obama's father lost his job and was eventually banished from the government because he opposed the tribal politics being played out in the government. When one thinks about Kenyans battling Kenyans, it is hard to be convinced that the Afrocentric claims of a global and trans-historical cultural unity among Africans has any meaning on the ground. Obama observes these divisions even among his relatives. He writes:

\begin{abstract}
Most Kenyans still worked with older maps of identity, more ancient loyalties. Even Jane or Zeituni could say things that surprised me. "The Luo are intelligent but lazy", they would say. Or "The Kikuyu are money-grubbing but industrious". Or "The Kalenjins - well you can see what's happened to the county since they took over".

Hearing my aunts traffic in such stereotypes, I would try to explain to them the error of their ways. "It's thinking like that that holds us back", I would say. "We're all part of one tribe. The black tribe. The human tribe. Look what tribalism has done to places like Nigeria or Liberia".

And Jane would say, "Ah, those West Africans are all crazy anyway. You know they used to be cannibals, don 't you?" (Obama 2004b: 348).
\end{abstract}

In a sense, Obama, the non-Afrocentrist, is ultimately as desiring of cultural unity as Afrocentrists. He simply wishes for an even more expansive unity than the Afrocentrists. Afrocentrists believe in a global black tribe, but Obama does not stop there. He wishes for a global human tribe. Meanwhile, the evidence suggests that even within a relatively small place like Kenya, the Luo, Kikuyu, Kalenjins and the other tribes are not quite as committed to unity as either the Afrocentrists or Obama. 
One problem that Africa poses for Afrocentrists is the lack of unity among Africans. Another is the lack of cultural purity among Africans. A Kenyan historian explains to Obama that black Americans are sometimes disappointed with Africa "because they come here looking for the authentic" (Obama 2004b: 433). She provides examples from a meal that she is sharing with Obama:

Kenyans are very boastful about the quality of their tea, you notice. But of course we got this habit from the English. Our ancestors did not drink such a thing. Then there's the spices we used to cook this fish. They originally came from India, or Indonesia. So even in this simple meal, you will find it very difficult to be authenticalthough the meal is certainly African (Obama 2004b: 433).

Black Americans looking for a culturally pure Africa cannot find it in contemporary Africa. Further, Africa, like the lives of black Americans themselves, belies the claim of a fundamental and distinct black and white culture. In this respect, the idea of a single human tribe seems more of a possibility than a pure African or pure European one.

\section{Conservatism and Mainstream Success in "Radical” Afrocentrism}

The ultimate goals of the black-nationalist activism of the Afrocentric era were missed by most critics. Perhaps because the critics heard the clear echoes of Black Power era cultural nationalism, they were unable to appreciate the differences between the Black Power and Afrocentric eras. Black Power era nationalism had radical aspirations. Most Black Power activists were interested in left-leaning political and economic change. Some claimed to be revolutionaries, others were liberal reformers and many were interested in increasing the amount of political separation between blacks and whites (Austin 2006a).

Afrocentric era black nationalists adopted and built on the African-focused cultural ideas of the Black Power era, but they left the radical politics and political separatism behind. Afrocentrists were ultimately interested in applying a conservative, values-based approach to the problems of poverty, violence and teen pregnancy facing black America (Austin 2006a). We can see this fact most clearly in the area of school reform.

Afrocentrists were fairly successful in their educational reform efforts. Many schools adopted curricula reforms that placed more emphasis on black and African history. Barack Obama had direct contact with an Afrocentric educator during his organizing years. He describes the office of the educator named Asante (not Molefi Kete Asante):

It was decorated with African themes: a map of the continent, posters of ancient Africa's kings and queens, a collection of drums and gourds and a kente-cloth wall hanging. . . . [Asante] was dressed in an African print, an elephant-hair bracelet around one thick wrist. He seemed a bit put off at first - he had a stack of SAT practice exams on his desk ... (Obama 2004b: 277-8).

The African-themed decorations are typical for an Afrocentric school (Austin 2006a: 147-152). It is significant that this educator has SAT practice exams on his desk. The SAT 
is one of the main exams used for entrance into higher education in the United States ${ }^{6}$. This Afrocentric educator, like most others, hoped that his students would go on to college and mainstream success. Janice Hale, another Afrocentric educator, is explicit about this goal. She sees her Afrocentric curriculum as leading blacks to "upward mobility, career achievement, and financial independence in the American mainstream" (quoted in Wieder 1992: 35).

The Asante that Obama met explained that a proper education for black students would "start by giving a child an understanding of himself, his world, his culture, his community" (Obama 2004b: 258). What Asante means is that education for black students should connect black students' identities to Africa. He states:

I expose students to African history, geography, artistic traditions. I try to give them a different values orientation - something to counteract the materialism and individualism and instant gratification that's fed to them the other fifteen hours of their day. I teach them that Africans are communal people. That Africans respect their elders (Obama 2004b: 259).

Asante sees the dangers resulting from the lack of Afrocentric education as being acute for boys because:

Half of them don't even know their own fathers. There's nobody to guide them through the process of becoming a man . . . to explain to them the meaning of manhood. And that's a recipe for disaster. Because in every society, young men are going to have violent tendencies. Either those tendencies are directed and disciplined in creative pursuits or those tendencies destroy the young men, or society, or both (Obama 2004b: 258).

For Asante, Afrocentric education provides endangered black males with the proper socialization into manhood. This socialization, he believes, would reduce the amount of violence in black communities.

There were some schools that were entirely Afrocentric and targeted to black males only. Not surprisingly, these schools were quite controversial. But as separatist as these schools seemed, no Afrocentist called for blacks to return to Africa as classical black nationalists did. No Afrocentrist called for a separate black nation within the geographical United States as a few Black Power nationalists did (Austin 2006a: 192).

For Afrocentrists, this separatism was merely a means to more effectively educate what they saw as an "endangered" black male population (see Gibbs 1988). This policy was similar to the way one would create a reserved space for an endangered plant or animal as a means of restoring the population back to health. For example, the principal of the Afrocentric Malcolm X Academy in Detroit, one of the schools that attempted to be for black males only, selected a black male student who went off to serve in the U.S. military as the type of success his school produces. This example shows clearly that the school is not about a radical separation from the United States (Watson and Smitherman 1996: 145).

6 Scores on the SAT is one measure used in determining whether a student will be admitted into selective colleges in the United States. At one time SAT stood for "Scholastic Aptitude Test", but controversies of aptitude or intelligence tests has caused the manufacturer to drop the aptitude claim but the acronym remains. The SAT is one of two major standardized tests used for determining admittance into selective colleges. 
Afrocentric educators were not interested in developing a new cadre of black revolutionaries as Black Power activists were. Rather, they were merely interested in reducing the rates of black poverty, criminal activity and teen pregnancy. For Hannibal Tirus Afrik, like that of Obama's Asante, the goal of Afrocentric education was to see that black youth stop "rebelling against traditional family authority structures" and harming black communities. Afrik saw Afrocentrism as ultimately battling against "the prolifieration of drugs, the easy accessibility of guns and weapons and the increase in media sensationalism of sexuality" (Afrik 1995). Jawanza Kunjufu, another Afrocentric educator, characterized this battle as Maat - an ancient Egyptian value system according to Afrocentrists - versus the values of hip-hop (Kunjufu 1993: iii). For Kunjufu, "One of the most revolutionary things you can do is to keep your marriage intact and raise your children" (Kunjufu 1996: 145). In Black Power era nationalism a revolutionary act might be to "Off the Pig!" - kill a police officer - as members of the Black Panthers might say, in Afrocentric era nationalism all one would need to do is get married and have kids.

It was difficult for many to see that the ultimate goals of Afrocentrism were perfectly mainstream and conservative American goals because they were wrapped inside a professed opposition to Eurocentrism - to white culture. But just as the Africa imagined in Afrocentrism has little to do with the actual lives of Africans, the "Eurocentrism" rejected by Afrocentrists also has little to do with the actual lives of whites. Maulana Karenga, who was a Black Power and an Afrocentric activist in the respective eras, described a person embodying the Afrocentic values of Maat as being "modest, wise, gentle and socially active" (Karenga 1986: 94). Individuals embodying Eurocentric values, however, are considered here as individualistic, materialistic, patriarchal and violent, among other aspects. Afrocentrists understood the problems of poverty, violence and teen pregnancy as the result of blacks adopting Eurocentric values. Eurocentric values were also characterized as drug-culture values or hip-hop values depending of the Afrocentrist. In mainstream American thought, "drug-culture values" might be seen as the values of a dysfunctional black culture. In Afrocentric thought, "drug-culture values" were also seen as the values of a dysfunctional black culture, but that culture was dysfunctional because it embraced Eurocentrism (Austin 2006a: 114-118).

Critics, who perceived Afrocentrism as radical, anti-American ideas, might argue that what poor blacks really needed was to embrace white, middle-class values and reject Afrocentrism. Afrocentrists would argue that what poor blacks really needed was to reject white, Eurocentric values and embrace Afrocentric values. What these two groups did not understand is that they were really both arguing for the same things. They simply had different labels for the same values. The critics called it middle-class values; the Afrocentrists, African values. Although Barack Obama is no Afrocentrist, he accepts the conventional wisdom that bad black values play an important role in black disadvantage. In The Audacity of Hope, he states, "We know that many in the inner city are trapped by their own self-destructive behaviors", and that "perhaps the single biggest thing we could do to reduce [inner city] poverty is to encourage teenage girls to finish high school and avoid having children out of wedlock" (Obama 2006: 255-256). He has also given speeches calling for blacks to value education more (Elliot 2007) and for black men to be more responsible (Obama 2008).

When one examines, the evidence, however, these arguments are not very convincing (see Austin 2006c). For example, black teen pregnancy declined significantly during the 1970s (National Center for Health Statistics 2007: 132), but there was no corresponding 
decline in black poverty (U.S. Census Bureau 2007). Contrary to the popular stereotype, the survey data and test score trends show that black students do value education (Austin 2007a; Austin 2007b), but socioeconomic disadvantage in black families and in black schools prevent them for achieving at the level of white students (Farkas 2008). The historical economic evidence is quite strong that tight labor markets increase black employment rates and wages, and that the higher income from these developments reduce black poverty (Mishel, Bernstein and Allegretto, forthcoming: 316-325).

\section{Self-Esteem - Defined by Others}

In the logic of Afrocentrism, African culture was presumed to increase black selfesteem and higher self-esteem would lead to a variety of positive social outcomes. Molefi Kete Asante argued: "what I want for blacks is the same self-esteem that white children automatically get when they walk into a class" (Newsweek 1991: 46). Afrocentric educators claimed that their curricula would "enhance self-esteem, motivate achievement, and help [students] to be law-abiding citizens" (Miller 1993: 58). For instance, Kunjufu's (n.d.) curriculum is called Self-Esteem through Culture Leads to Academic Excellence.

The view that low self-esteem lay at the root of social problems was another very mainstream American idea in Afrocentrism. In I'm Dysfunctional, You're Dysfunctional, Wendy Kaminer's 1992 anti-popular psychology book, she observes, "On almost every [television talk show], someone is bound to get around to self-esteem; most forms of misconduct are said to be indicative of low self-esteem" (Kaminer 1992: 36). Barack Obama made a similar observation. He remarks, "By the time I reached Chicago, the phrase self-esteem seemed to be on everyone's lips: activist, talk show hosts, educators, and sociologists" (Obama 2004b: 193).

In Dreams of My Father, Obama seems ambivalent about whether self-esteem has real merit for understanding the social problems in black America. He argues:

But whenever I tried to pin down this idea of self-esteem, the specific qualities we hoped to inculcate, the specific means by which we might feel good about ourselves, the conversation always seemed to follow a path of infinite regress. Did you dislike yourself because of your color or because you couldn't read and couldn't get a job? (Obama 2004b: 193-4).

On the other hand, he comes to see the blue contact lenses that a fellow organizer, Ruby, wears as evidence as low self-esteem. To this example, he adds all of the anti-black attitudes that he hears from blacks (Obama 2004b: 192-5).

Obama discounted Ruby's statement that the blue contacts were "just for fun" (Obama 2004b: 192). Molefi Kete Asante would likely agree that the blue contacts signified black self-hatred, and he might even go further. Most black women's hair is naturally as tightly curled as black men's hair. However, most black American women straighten their hair. No doubt, this practice arose to make black women's hair look more like white women's hair. Molefi Kete Asante (1988) has critized black women for their "blond wigs, [their] fried, dyed and swept to the side hairstyles" (30). In addition to chemical straighteners, black women use heated metal combs and flat irons which "fry" their hair straight. Michelle Obama's hair is not blond but it can be called "fried" and "swept to the side". Nationalists have often insisted on "natural" hairstyles as proof of black women's self-love. Just as Obama, saw the blue contacts as evidence of Ruby's low self-esteem, Afrocentrists may look at his wife's and daughter's hair as evidence of their low self-esteem. Although 
the popular psychology of self-esteem is quite compelling, little of it is based on a real understanding of the complexities of the human psyche (Austin 2006a: 138-141).

\section{The Perplexing Trinity United Church of Christ}

Jesus was a poor black man who lived in a country and who lived in a culture controlled by rich white people. The Romans were rich; the Romans were Italian which means they were European which means they were white; and the Romans ran everything in Jesus' country.

The government gives them the drugs, builds bigger prisons, passes a three-strike law and then wants us to sing "God Bless America". No, no, no, not "God bless America", "God damn America"! Reverend Jeremiah A. Wright, Jr. ${ }^{7}$

Barack Obama came to Christianity through the ministry of the Reverend Jeremiah A. Wright, Jr., the former leader of the Trinity United Church of Christ. Trinty was Obama's church until controversial statements like the ones quoted above came to the attention of the American public. For individuals with contact with the various ideological strands of thought in black America, none of Reverend Wright's statements are new ${ }^{8}$. What is surprising is that they were made by such a prominent individual in such a prominent church. Individuals in Reverend Wright's position are usually more moderate, with more mainstream ideas.

During the Black Power era, the black theologian James Cone melded black Christianity and Black Power ideology. In 2007, when Cone was asked which church best exemplifies his Black Power Christian theology, he pointed to Trinity under the leadership of Reverend Wright (Byassee 2007: 21). Trinty's motto is "Unashamedly Black, Unapologetically Christian", and it rejected "the Pursuit of Middleclassness" (Speller 2005: 91-92). The Church states that God "is not pleased with America's economic maldistribution". These economic ideas place the Church in the ideological realm of Black Power (Austin 2006a: 74-109).

Trinity also fits ideologically within the more recent Afrocentric era. Julia Speller who has studied the history of Trinity reports that "in the late 1980s and early 1990s" the congregation began "the move from being 'Unashamedly Black' to being more explicitly Africentric" (Speller 2005: 92).

In 1992, the administration began to understand its Purpose in a new way as it decided to change the name of the Bible Study Development Center to the Center for African Biblical Studies. "Our goal was to consistently reflect the emerging emphasis on our African heritage in light of biblical tradition, said Deacon Shirley Bims-Ellis, director. . . The classes, consequently, included a focus on the African origins of Christianity, the African presence in the Bible, and use of maps to provide a visual connection between the stories in the Bible and the geographic connection to the continent of Africa (Speller 2005: 93).

7 Quotations transcribed from www.youtube.com videos "Jeremiah Wright: Promoting the Hate", http:// www.youtube.com/watch?v=c4WMqlfiQKo and "Reverend Wright hate", http://www.youtube.com/ watch? $\mathrm{v}=8 \mathrm{M}-\mathrm{kD} 0 \mathrm{QdRJk}$.

8 As much as one-third of blacks conceive of Jesus as black, for example (Cunnien 2008).

9 This quotation was on Trinity's website before the site was re-designed in September 2008. 
Trinity's members also regularly wear African-inspired clothing. The website has, until recently, had a kente-cloth motif. The Church has rites of passage programs for boys and girls. These rites programs became popular during the Afrocentric era since the improper socialization of black youth was defined as one of the problems afflicting black America.

Trinity is a chimera of a church. It is not uncommon to find that former Black Power activists transformed themselves into Afrocentric activists (Austin 2006a: 191). Molefi Kete Asante, for example, during the Black Power era argued that "Pan-Africanism without socialism [is] self-defeating because otherwise the exploitation of the people would continue at the hands of black exploiters" (Asante 1978: 115). In the Afrocentric era, Asante discarded socialism. He stated that a black American can "work for IBM and live in the suburbs and be Afrocentric" (quoted in Jacoby 1994). Trinity - and Reverend Wright - , however, did not transform. They merged Black Power and Afrocentrism into one hybrid philosophy.

The membership of the church is also hybrid. Normally, black churches, like many other churches, are organized along major social divisions, including class divisions. Obama admired Reverend Wright for his "ability to hold together, if not reconcile, the conflicting strains of black experience" (Obama 2004b: 282).

We got a lot of different personalities here", he told [Obama]. "Got the Africanist over here. The traditionalist over here. Once in a while, I have to stick my hand in the pot - smooth things over before stuff gets ugly. But that's rare. Usually, if somebody's got an idea for a new ministry, I just tell 'em to run with it and get outta their way (Obama 2004b: 282).

Apparently, the multifaceted-ness of Trinity opened it to multiple lines of criticism. Wright stated to Obama:

Some of my fellow clergy don't appreciate what we're about. They feel like we're too radical. Others, we ain 't radical enough. Too emotional. Not emotional enough. Our emphasis on African history, on scholarship - "

"Some people say", [Obama] interrupted, "that the church is too upwardly mobile. The reverend's smile faded. "That's a lot of bull", he said sharply (Obama 2004b: 283).

What might prompt the upwardly mobile view is that the church has black middleclass members and has had a few celebrities in its ranks including Oprah Winfrey, the rapper and actor Common (Byassee 2007: 18), and the Senator Barack Obama.

The fact that Wright is insulted by the "upwardly mobile" comment reveals his Black Power bona fides. Currently, black preachers are moving to "prosperity gospel" that argues that God wants the faithful to prosper financially (Potter 2007). Followers of prosperity gospel would take the upwardly mobile charge as a badge of honor. Afrocentrists would be indifferent to the accusation of being upwardly mobile since they tend not to have a class analysis. A Black Power leftist, however, would be upset by the upward mobility charge.

Why would a smart politician like Barack Obama find himself in a hybrid Black Power-Afrocentric church? For someone with presidential aspirations, it is not a smart move. But Obama was not always running for president. Reverend Wright was influential in black Christian life in Chicago. Obama (2004b) reported, "When I asked for other pastors to talk to, several gave me the name of Reverend Wright" (Obama 2004b: 280). 
Any one influential among black Christians is influential in black Chicago generally since blacks are very religious and the black church is still an important base for social activism in black communities. Any smart Chicago politician would want to have an important black church leader by his side.

Reverend Wright was not just an influential church leader. He had more to offer. Wright had a diverse ministry in terms of social class. That is a special and unique benefit. A politician in Wright's church would be able to connect to poorer constituents and to middle-class individuals who could also provide skills, money and connections to others with resources for a political campaign. For this reason also, it was smart for Obama to be a member of Trinity.

It is possible that Wright may have provided something else to Obama. The ability to unite a diverse black community in one church is an amazing feat. Barack Obama's presidential campaign is based upon uniting a diverse America behind him. Obama may have learned some of his skills as a uniter as a student of Reverend Wright.

\section{Chicago Black Nationalism during the Afrocentric Era}

It is not at all surprising that a Black Power-Afrocentric church would be located in Chicago. Chicago was an extremely vibrant place for black nationalism during the Afrocentric era. The Nation of Islam and its leader the Minister Louis Farrakhan is headquartered in Chicago. During the Afrocentric era, the Nation of Islam organized the Million Man March, the largest assembly of black men in U.S. history. The March was directed at the need for black men to atone and provide a positive image of themselves. In considering thus implicitly black men as the problem and not racial discrimination in American society, the themes of the March fit with the conservative politics of the Afrocentric era (Austin 2006a: 161-166).

A number of influential scholars and organizations were also located in Chicago. Dr. Jacob Carruthers, one of the pre-eminent Afrocentric Egyptologists, worked out of the Chicago branch of Northeastern Illinois University. His Kemetic Institute was a training ground for the next generation of Afrocentric scholars. Haki Madhubuti is another important author Chicago-based black-nationalist author. Madhubuti, formerly Don L. Lee, was also an influential Black Power author, and he, like others, became more Afrocentric during the Afrocentric era. Madhubuti is the founder of Third World Press which publishes Afrocentric literature. During the Afrocentric era, one also found Conrad Worrill in Chicago, the head of the black nationalist National Black United Front (NBUF). Worrill and NBUF are like Trinity church, embracing Black Power and Afrocentric black nationalism.

A major success of Afrocentrism was its infusion in school curricula. There were a number of individuals in Chicago who were leaders in this effort. Dr. Carruthers and his Kemetic Institute provided training for teachers. Madhubuti and his wife, Carol Lee, led two Afrocentric schools. Hannibal Tirus Afrik led another. Madhubuti, Lee and Afrik also provided guidance to others interested in starting similar schools. Jawanza Kunjufu, also Chicago-based, developed his curriculum Self-Esteem through Culture Leads to Academic Excellence. Kunjufu also runs an Afrocentric publishing house, African American Images.

It should be noted that the idea that black males are an endangered species was supported by the works of two Chicago black-nationalist authors. Kunjufu authored Countering the Conspiracy to Destroy Black Boys and Madhubuti wrote Black Men: Obsolete, 
Single, Dangerous? Both of these books were very popular during the Afrocentric era and highlighted the troubles facing black males. The Million Man March should be understood as also responding to the perceived black-male crisis.

When one considers that Obama circulated in a city with some of the major blacknationalist leaders and major black nationalist organizations, it becomes less surprising that a mainstream politician would have black nationalist connections. He would have been a bad politician, had he not made these connections. Life in black Chicago, at least, partially explains how a mainstream politician ended up connected to someone as antimainstream as Reverend Wright.

\section{Conclusion}

There are many ironies and contradictions in Afrocentrism ${ }^{10}$. One is that Afrocentrism is most appealing to blacks who have had significant experience outside Africa. The Afrocentrism of the Afrocentric era was born in the United States, not imported from Africa (Austin 2006a: 112-114). Deep engagement with Africa is often an anti-Afrocentric experience. Obama's experiences in Africa pushed back against Afrocentric ideas of cultural unity and cultural purity.

The ideas of the Afrocentric era, thus, teach us more about blacks in America in the late-1980s and 1990s, than about African culture. Afrocentrism reveals the power of conservative "family values" ideas in American culture. Afrocentrists accepted the ideas that black poverty and other social problems were cultural - not political and economic problems that required a cultural solution. This view, that bad cultural values is the cause of black disadvantage, persists although the Afrocentric era (that is the intense Afrocentric activism of the 1990s) has passed. Obama rejects Afrocentrism in favor of universalism, but he does not reject the idea that "many in the inner city are trapped by their own selfdestructive behaviors". In this respect, his ideas are in perfect accord with Afrocentrists and with much of contemporary American popular opinion.

Afrocentrism is a form of nationalism and like all nationalisms it strives to build an imagined community (Anderson 1991). In the case of Afrocentrism, the community imagined is a trans-historical, global black community. Barack Obama aspired to and obtained the presidency of the United States. While it has been possible for some American presidents and aspirants to the American presidency to make appeals to a white-American nationalism and an imagined white-American community (Hsu 2009: 49, 54; Ambinder 2009: 64), Barack Obama cannot. As a black man, white-American nationalism rejects him as a legitimate leader of the United States. In a country where blacks are a minority, Obama also cannot immerse himself in black nationalism and be seen as a legitimate leader of the United States. Obama's path to the presidency therefore necessitated getting Americans to imagine a post-racial and multicultural American community. His personal biography, however, likely makes this ideal of a non-race-based unity as much a natural reflex as a calculated political strategy (Ambinder 2009).

Obama has repeatedly worked to have Americans imagine a racially and culturally inclusive American community. His inaugural celebration included a concert with a racially diverse collection of performers called "We Are One". The goal of the concert was to connect "music to [American] history and ideas and American values". The concert's

10 See Austin 2006a, pp. 124-126, for a specific discussion of contradictions. 
"theme of inclusiveness" led to an "array of performers from varied musical genres" including "[c]ountry, gospel, jazz, rock, pop and hip-hop" (Leiby 2009). This vision of a multiracial, multicultural America has been a recurring theme in Obama's speeches. In his inaugural address, he stated:

For we know that our patchwork heritage is a strength, not a weakness. We are a nation of Christians and Muslims, Jews and Hindus, and non-believers. We are shaped by every language and culture, drawn from every end of this Earth; and because we have tasted the bitter swill of civil war and segregation, and emerged from that dark chapter stronger and more united, we cannot help but believe that the old hatreds shall someday pass; that the lines of tribe shall soon dissolve; that as the world grows smaller, our common humanity shall reveal itself; and that America must play its role in ushering in a new era of peace (Obama 2009).

Here again we see Obama the universalist. President Obama's nationalist appeals will always be to an imagined race-transcendent American nation and not to the Afrocentrist's global black community. And, thus, a black man with a Kenyan father is not only America's Commander in Chief, he is also the anti-Afrocentrist in chief.

\section{References cited}

Afrik, Hannibal Tirus, 1995 "Rites of Passage Convention Set”, New Pittsburg Courier, 8 July, p. A7.

Ambinder, Marc, 2009. “Race Over?”, The Atlantic, January/February, pp. 62-65.

Anderson, Benedict, 1991. Imagined Communities: Reflections on the Origin and Spread of Nationalism. New York: Verso.

Asante, Molefi Kete,

1978. "Systematic Nationalism: A Legitimate Strategy for National Selfhood”, Journal of Black Studies, 9 (1), September, pp. 115-128.

1987. The Afrocentric Idea. Philadelphia: Temple University Press.

1988. Afrocentricity, (new rev. ed.). Trenton, NJ: Africa World Press.

Austin, Algernon,

2006a. Achieving Blackness: Race, Black Nationalism and Afrocentrism in the Twentieth Century. New York: New York University Press.

2006b. “Are Africans in America African Americans?”, Black Directions, 2 (2).

2006c. Getting It Wrong: How Black Public Intellectuals Are Failing Black America. New York: iUniverse, Inc.

2007a. "The Truth about 'Acting White': What the Pundits and the Media Aren't Telling You”, Black Directions, 2 (3).

2007b. "The Truth about Black Students: What the Pundits and the Media Aren't Telling You", Black Directions, 2 (4).

Byassee, Jason, 2007. “A Visit to Chicago's Trinity UCC Africentric Church”, Christian Century, 29 May.

Clarke, John Henrik, 1997. Foreword to African World History Project: The Preliminary Challenge, ed. Jacob H. Carruthers and Leon C. Harris. Los Angeles, CA: Association for the Study of Classical African Civilizations. 


\section{Barack Obama and the Ironies of Afrocentrism}

Cunnien, Keith A., 2008. "What Would Jesus Protest?”, Contexts, Summer 2008, p. 9.

Decker, Jeffrey Louis, 1993. "The State of Rap: Time and Place in Hip Hop Nationalism”, Social Text, 34, pp. 53-84.

Elliot, Debbie, 2007. “Obama, Clinton Reflect on Selma’s Lengthy Shadow”, Weekend All Things Considered, National Public Radio, 4 March.

FARKAs, George, 2008. "How Educational Inequality Develops", in The Colors of Poverty: Why Racial and Ethnic Disparities Persist. New York: Russell Sage Foundation, pp. 105-134.

GibBs, Jewel Taylor, 1988. Young, Black, and Male in America: An Endangered Species. Westport, CT: Auburn House.

Hill, Robert A. and Carol A. Rudisell (eds), 1983. The Marcus Garvey and Universal Negro Improvement Association Papers. Berkeley: University of California Press.

Hilliard, Asa, 1998. SBA: The Reawakening of the African Mind. Gainesville, FL: Makare Publishing Company.

Hsu, Hua, 2009. "The End of White America”, The Atlantic, January/February.

JACKSON, Jr., John, 2001. Harlemworld: Doing Race and Class in Contemporary Black America. Chicago: The University of Chicago Press.

JACOBY, Russell, 1994. "The Most Radical Afrocentric Ideologue Is Culturally an American", Chronicle of Higher Education, 30 March 1994, p. B5.

Kaminer, Wendy, 1992. I'm Dysfunctional, You're Dysfunctional: The Recovery Movement and Other Self-Help Fashions. Reading, MA: Addison-Wesley.

Karenga, Maulana, 1986. "Restoration of the Husia: Reviving a Sacred Legacy", in Kemet and the African Worldview: Research, Rescue and Restoration, Maulana Karenga and Jacob H. Carruthers (ed.). Los Angeles: University of Sankore Press, pp. 83-100.

Kilborn, Peter T., 1988. "Economic Nationalism Shapes Democratic Campaign Debate”, New York Times, 22 March, p. A1.

Kunjufu, Jawanza,

n.d. SETCLAE (Self-Esteem Through Curriculum Leads to Academic Excellence). Chicago: African American Images.

1993. Hip-Hop vs. MAAT: A Psycho/Social Analysis of Values. Chicago: African American Images.

1996. Restoring the Village, Values, and Commitment: Solutions for the Black Family. Chicago: African American Images.

LEIBY, Richard, 2009. "Stars of All Stripes Line Up for Concert at Lincoln Memorial”, The Washington Post, January 13, A01.

Miller, John J., 1993. “Afrocentrism in the Suburbs”, National Review, 45 (18), p. 58.

Mishel, Lawrence, Jared Bernstein and Heidi Shierholz, forthcoming [2009]. The State of Working America 2008/2009. Ithaca, NY: Cornell University Press.

Moses, Wilson Jeremiah, 1978. The Golden Age of Black Nationalism, 1850-1925. New York: Oxford University Press.

National Center For Health Statistics, 2007. Health, United States, 2007. Hyattsville, MD: National Center for Health Statistics.

New York Times, 1988. “Jackson and Others Say 'Blacks' is Passe”, New York Times, 12 December, p. A12.

NewsweEK, 1991. 23 September 1991. 
OBAма, Barack,

2004a. "The Audacity of Hope", 2004 Democratic National Convention Keynote Address, http://www. americanrhetoric.com/speeches/convention2004/barackobama2004dnc.htm.

2004b. Dreams of My Father: A Story of Race and Inheritance. New York: Three Rivers Press.

2006. The Audacity of Hope: Thoughts on Reclaiming the American Dream. New York: Three Rivers Press.

2008. "Remarks of Senator Barack Obama:Apostolic Church of God", 15 June, http://www.barackobama. com/2008/06/15/remarks_of_senator_barack_obam_78.php.

2009. "President Barack Obama’s Inaugural Address", 20 January, http://www.whitehouse.gov/blog/ inaugural-address/.

PotTer, Deborah, 2007. "Prosperity Gospel”, Religion and Ethics Newsweekly, 17 August, http://www.pbs.org/ wnet/religionandethics/week1051/feature.html.

RuETERS, 1988. "Jackson Apologies for a Slur but Balks at Farrakhan Split”, New York Times, 17 April.

Schaefer, Richard T., 2000. Racial and Ethnic Groups, $8^{\text {th }}$ ed. Upper Saddle River, NJ: Prentice Hall.

Speller, Julia, 2005. Walkin' the Talk: Keepin'the Faith in Africentric Congregations. Cleveland: The Pilgrim Press.

U.S. Census Bureau, 2007. “Table 2”, Historical Poverty Tables. Washington, D.C.: U.S. Census Bureau. http:// www.census.gov/hhes/www/poverty/histpov/hstpov2.xls.

Van Deburg, William L., 1992. New Day in Babylon: The Black Power Movement and American Culture, 1965 1975. Chicago: University of Chicago Press.

Watson, Clifford and Geneva Smitherman, 1996. Educating African American Males: Detroit's Malcolm X Academy Solution. Chicago: Third World Press.

Wieder, Alan, 1992. "Afrocentrisms: Capitalist, Democratic, and Liberationist Portraits", Educational Foundations, Spring, pp. 32-42. 